\title{
IDENTIFIKASI SEKTOR EKONOMI UNGGULAN DAN KETIMPANGAN PENDAPATAN ANTAR KABUPATEN DI SUB DAS BENGAWAN SOLO HULU
} (Identification of the Leading Economic Sectors and Income Disparity among Regencies in Upper Bengawan Solo Sub Watershed)

\author{
S. Andy Cahyono ${ }^{1} \&$ Wahyu Wisnu Wijaya ${ }^{2}$ \\ 1,2Balai Penelitian Teknologi Kehutanan Pengelolaan Daerah Aliran Sungai \\ Jl. Jend A. Yani-Pabelan, Kartasura. PO BOX 295 Surakarta 57102 Telp/Fax: (0271) 716709; 716959 \\ e-mail: sandycahyono@yahoo.com
}

Diterima 8 Juli 2013, direvisi 11 Februari 2014, disetujui 21 Februari 2014

\begin{abstract}
The purposes of this study are: (1) to identify leading economic sectors and (2) to analyse income disparity among regencies in Upper Bengawan Solo sub watershed. The study covers 5 regencies: Wonogiri, Boyolali, Klaten, Sragen and Karanganyar. Data were analyzed using a Klassen typology to determine pattern and economy structure, Location Quotient (LQ) to identify leading economic sectors, Williamson Index to determine economic disparity and sectoral contribution to determine role of sector. The results show that leading economic sectors were different for each regency, i.e. Wonogiri (transport and communications), Karanganyar (processing industry), Boyolali (finance, real estate, and business services), Sragen (agriculture, livestock, forestry, and fisheries), and Klaten (construction). The leading sectors identified in each regency varied depending on the endowment of resources and comparative advantage. Based on their pattern and economy structure, Karanganyar can be categorized as advanced and fast growing region but Wonogiri as disadvantaged regions. The results also show that the income disparity among regencies was low $(0.25)$ and tended to increase. The development policy of bigh economic growth with low disparity can be inclusively done by developing the leading sectors and paying attention to the economic transformation that occurred in each regency.
\end{abstract}

Keywords: Upper Bengawan Solo sub watershed, regency, key economic sector, income disparity

\begin{abstract}
ABSTRAK
Tujuan penelitian ini adalah untuk (1) mengidentifikasi sektor ekonomi unggulan dan (2) menganalisis ketimpangan pendapatan antar kabupaten di Sub DAS Bengawan Solo Hulu. Penelitian dilakukan di 5 kabupaten: Wonogiri, Boyolali, Klaten, Sragen, dan Karanganyar. Analisis data menggunakan tipologi Klassen untuk mengetahui pola dan struktur ekonomi, Location Quotient (LQ) untuk mengidentifikasi sektor unggulan, Indeks Williamson untuk mengetahui disparitas ekonomi, dan kontribusi sektoral untuk mengetahui peran sektoral. Hasil penelitian menunjukkan bahwa sektor unggulan berbeda tiap kabupaten, yaitu Wonogiri (pengangkutan dan komunikasi), Karanganyar (industri pengolahan), Boyolali (keuangan, real estat, dan jasa perusahaan), Sragen (pertanian, peternakan, kehutanan, dan perikanan), dan Klaten (konstruksi). Sektor ekonomi unggulan di setiap kabupaten bervariasi tergantung ketersediaan sumberdaya dan keunggulan komparatif. Berdasarkan pola dan struktur ekonominya, Kabupaten Karanganyar termasuk daerah maju dan berkembang pesat tetapi Wonogiri termasuk daerah terbelakang. Hasil penelitian juga menunjukkan disparitas pendapatan antar daerah di masingmasing kabupaten terkategori rendah $(0,25)$ dan cenderung meningkat. Kebijakan pembangunan ekonomi dengan pertumbuhan ekonomi tinggi dan disparitas rendah dapat dilakukan dengan pengembangan sektor unggulan secara inklusif dan memperhatikan transformasi ekonomi yang terjadi di tiap kabupaten.
\end{abstract}

Kata kunci: Subdas Bengawan Solo Hulu, kabupaten, sektor unggulan, ketimpangan pendapatan

\section{PENDAHULUAN}

Pembangunan ekonomi daerah merupakan suatu proses dimana pemerintah daerah dan masyarakat mengelola sumberdaya dan membentuk suatu pola kemitraan antara pemerintah daerah dan sektor swasta untuk menciptakan lapangan kerja dan merangsang perkembangan kegiatan ekonomi (pertumbuhan ekonomi) dalam daerah tersebut (Arsyad, 1999). Indikator keberhasilan 
pembangunan dapat dilihat dari pertumbuhan ekonomi, pemerataan keadilan, dan keberlanjutan (Rustiadi et al., 2011; Isnowati, 2012; Jonaidi, 2012; Van de Werfhorst dan Salverda, 2012; Adisasmita, 2013; Ernita et al., 2013). Pertumbuhan ekonomi merupakan suatu perubahan tingkat ekonomi yang berlangsung dari tahun ke tahun (Sukirno, 1994).

Ketimpangan antar daerah merupakan salah satu permasalahan dalam pembangunan daerah (Wilonoyudho, 2009; Sufirmansyah, 2012), termasuk dalam suatu daerah aliran sungai (DAS). DAS bagian hulu umumnya menghadapi kerusakan lingkungan yang semakin parah sehingga menurunkan produktivitas lahan, meningkatkan erosi dan sedimentasi serta kemiskinan. Ini mengakibatkan tingkat kemajuan ekonomi yang berbeda antar daerah di DAS bagian hulu (Syam, 2003). Konsekuensinya, ketimpangan ekonomi antar daerah dalam suatu DAS hulu tidak terelakan. Faktanya, terdapat semacam trade off antara pertumbuhan dan ketimpangan ekonomi (Kuncoro, 2004; Shin, 2012). Myrdal (1957) dalam Hidayati (2008) menunjukkan bahwa perbedaan tingkat kemajuan ekonomi antar daerah yang berlebihan dapat menyebabkan pengaruh yang merugikan terhadap perkembangan daerah secara keseluruhan.

Suatu daerah akan mengalami percepatan pertumbuhan apabila memiliki sektor ekonomi yang mampu mengakselerasi pembangunan dan sektor-sektor yang lain (Rustiadi et al., 2011). Untuk itu penentuan sektor ekonomi unggulan dalam pembangunan daerah adalah penting dilakukan sebagai upaya pengalokasian sumberdaya yang tersedia dengan tepat. Pertumbuhan sektor ekonomi unggulan di suatu daerah diyakini oleh Restiatun (2009) akan mendorong pertumbuhan dan perkembangan sektor-sektor ekonomi lain daerah setempat dan perekonomian daerah sekitar. Dalam hal ini daerah pengembangan sektor ekonomi unggulan akan meningkatkan penyerapan tenaga kerja dan sumberdaya daerah sekitar dan bagi daerah pengembangan sektor ekonomi unggulan sendiri akan meningkatkan ekspor produk dan jasa yang dihasilkan. Namun demikian, perkembangan suatu daerah yang cepat akan menimbulkan kesenjangan pendapatan antar daerah bila tidak secara tepat diantisipasi.

Sub DAS Bengawan Solo Hulu merupakan salah satu bagian dari DAS terbesar di Pulau Jawa, yaitu
DAS Bengawan Solo (BBWS Bengawan Solo, 2012). Permasalahan yang terdapat di Sub DAS Bengawan Solo Hulu adalah kompleks dan membutuhkan pengelolaan yang tepat dalam hal pola, struktur, dan kesenjangan ekonomi antar daerah dalam sub DAS. Dalam tulisan ini disajikan (1) hasil identifikasi sektor-sektor ekonomi unggulan di 5 kabupaten/kota dalam wilayah Sub DAS Bengawan Solo Hulu, yaitu: Wonogiri, Boyolali, Klaten, Sragen, dan Karanganyar, dan (2) hasil analisis ketimpangan pendapatan antar kabupaten/kota dalam wilayah Sub DAS yang bersangkutan. Penelitian ini diharapkan dapat memacu pertumbuhan sektor ekonomi unggulan dan mengurangi ketimpangan pendapatan antar kabupaten dalam DAS.

\section{METODE PENELITIAN}

\section{A. Lokasi Penelitian}

Penelitian dilakukan di 5 kabupaten dalam wilayah Sub DAS Bengawan Solo Hulu, yang berada pada $7^{\circ} 14^{\prime} 12,8^{\prime \prime} \quad-8^{\circ} 6^{\prime} 48,6^{\prime \prime}$ LS dan $110^{\circ} 26^{\prime} 39,5^{\prime \prime}-111^{\circ} 27^{\prime} 20,2^{\prime \prime}$ BT. Kelima kabupaten yang dikaji dan luasnya, yaitu: Wonogiri (1386,51 $\left.\mathrm{km}^{2}\right)$, Karanganyar $\left(783,53 \mathrm{~km}^{2}\right)$, Boyolali $(583,52$ $\left.\mathrm{km}^{2}\right)$, Sragen $\left(860,70 \mathrm{~km}^{2}\right)$, dan Klaten $(661,75$ $\mathrm{km}^{2}$ ). Total luas kelima kabupaten tersebut adalah sekitar 70,42 \% dari luas DAS Bengawan Solo Hulu seluas $\pm 6.072 \mathrm{~km}^{2}$ (Nippon Koei, 2001; Wikipedia, 2014). Luas DAS Bengawan Solo Hulu tersebut sekitar 38,08\% dari luas DAS Bengawan Solo (PPE Jawa, 2014). Penggunaan lahan DAS Bengawan Solo Hulu sebagian besar terdiri dari: sawah $(32,95 \%)$, pertanian lahan kering campur semak $(28,16 \%)$, pemukiman $(15,03 \%)$, pertanian lahan kering $(10,44 \%)$, dan hutan tanaman $(10,04 \%)$ (Nippon Koei, 2001).

\section{B. Pengumpulan Data}

Jenis data yang dikumpulkan meliputi: Produk Domestik Regional Bruto (PDRB) harga konstan dan berlaku, jumlah penduduk, laju pertumbuhan PDRB, dan data pendukung lain periode 20002011 dari kelima kabupaten dalam Sub DAS Bengawan Solo Hulu. Data dikumpulkan dari publikasi Badan Pusat Statistik (BPS) dan instansi lain yang relevan. 


\section{Analisis Data}

Berdasarkan data yang terkumpul, perekonomian di lima kabupaten dalam Sub DAS Bengawan Solo Hulu dianalisis dari sisi: (1) pertumbuhan dari tahun ke tahun (year on year), (2) pola dan struktur pertumbuhan, (3) disparitas pendapatan antar kabupaten, (4) sektor-sektor ekonomi unggulan, dan (5) kontribusi sektoral. Masing-masing analisisnya dijelaskan sebagai berikut:

\section{Pertumbuhan Ekonomi}

Pertumbuhan ekonomi dapat dilihat dari perkembangan nilai Produk Domestik Regional Bruto dari tahun ke tahun baik atas dasar harga berlaku maupun atas dasar harga konstan (Arsyad, 1997). PDRB atas dasar harga berlaku digunakan untuk melihat pergeseran dan struktur ekonomi, sedangkan PDRB atas dasar harga konstan digunakan untuk mengetahui pertumbuhan ekonomi dan membandingkan antar waktu. Penelitian ini menggunakan PDRB atas dasar harga konstan tahun 2000, dirumuskan:

$r=\frac{\left(P D R B_{t}-P D R B_{t-1}\right)}{P D R B_{t-1}} \cdot 100 \%$

di mana: $\mathrm{r}=$ pertumbuhan ekonomi; $\mathrm{PDRB}_{\mathrm{t}}=$

PDRB tahun ke $t$; dan PDRB $_{t-1}=$ PDRB tahun ke $\mathrm{t}-1$.

\section{Pola dan Struktur Pertumbuhan Ekonomi}

Untuk mengetahui pola dan struktur pertumbuhan ekonomi suatu kabupaten di Sub DAS Bengawan Solo Hulu digunakan Tipologi Klassen. Tipologi Klassen dapat digunakan dengan dua pendekatan, yaitu sektoral (Wardana, 2007; Chaniago, 2009) dan daerah (Sutarno dan Kuncoro, 2003; Caska dan Riadi, 2008; Hidayati, 2008; Arifin, 2009; Pujiati, 2009). Tipologi Klassen dalam penelitian ini menggunakan pendekatan daerah untuk menentukan pola dan struktur pertumbuhan ekonomi yang dapat memetakan atau menggolongkan kemajuan daerah berdasarkan pertumbuhan ekonomi dan pendapatan per kapita. Pertumbuhan ekonomi pada sumbu vertikal dan pendapatan per kapita pada sumbu horizontal. Berdasarkan hal tersebut, maka daerah diklasifikasikan menjadi (1) daerah cepat maju dan cepat tumbuh (high growth and high income), (2) daerah maju tapi tertekan (bigh income but low growth), (3) daerah yang berkembang cepat (bigh growth but low income) dan (4) daerah tertinggal (low growth and low income) (Rustiadi et al, 2011). Dalam bentuk matriks, analisis tipologi Klassen kabupaten dalam Sub DAS Bengawan Solo Hulu digambarkan pada Tabel 1.

Tabel 1. Matrik klasifikasi kabupaten dalam Sub DAS Bengawan Solo Hulu berdasarkan Tipologi Klassen Tabel 1. Matrix of regency classification in the Upper Bengawan Solo sub watershed based on Klassen Typology

\begin{tabular}{cll}
\hline \multirow{2}{*}{$\begin{array}{c}\text { Laju pertumbuhan } \\
(\text { Growth rate })(\mathrm{R})\end{array}$} & \multicolumn{1}{c}{$\begin{array}{c}\text { PDRB per kapita } \\
\text { (GRDP per capita) }(\mathrm{Y})\end{array}$} \\
\cline { 2 - 3 } & \multicolumn{1}{c}{ Yi $>\mathrm{Y}$} & \multicolumn{1}{c}{ Yi $<\mathrm{Y}$} \\
\hline $\mathrm{Ri}>\mathrm{R}$ & $\begin{array}{l}\text { Daerah maju dan cepat tumbuh } \\
\text { (Advanced and fast growing regions) }\end{array}$ & $\begin{array}{l}\text { Daerah berkembang cepat (Rapidly } \\
\text { growing regions) }\end{array}$ \\
\hline $\mathrm{Ri}<\mathrm{R}$ & $\begin{array}{l}\text { Daerah maju tapi tertekan } \\
\text { (Developed regions but depressed) }\end{array}$ & $\begin{array}{l}\text { Daerah tertinggal (Disadvantaged } \\
\text { regions) }\end{array}$ \\
\hline
\end{tabular}

Keterangan (Remark): $\mathrm{Ri}=$ laju pertumbuhan PDRB kabupaten/kota (GRDP growth rate of regency/city); $\mathrm{R}=$ laju pertumbuhan PDRB DAS (GRDP growth rate of watershed); Yi = PDRB per kapita kabupaten/kota (GRDP per capita of regency/city); $\mathrm{Y}=\mathrm{PDRB}$ per kapita di DAS (GRDP per capita of watershed).

\section{Disparitas Pendapatan Antar Kabupaten}

Disparitas pendapatan antar kabupaten dalam Sub DAS Bengawan Solo Hulu diukur dengan menggunakan Indeks Williamson. Indeks Williamson adalah suatu indeks yang didasarkan pada ukuran penyimpangan pendapatan per kapita penduduk tiap wilayah dan pendapatan per kapita nasional (Sjafrizal, 2012). Rustiadi et al., (2011) menyatakan bahwa indeks Williamson merupakan salah satu indeks yang paling sering dipergunakan untuk melihat disparitas antar wilayah. Indeks Williamson dirumuskan (Tambunan, 2003; Khairullah dan Cahyadin, 2006; Emilia dan Imelia, 2006; Rachman, 2010) sebagai berikut: 
$I w=\frac{\sqrt{\sum(Y i-\bar{Y})^{2} \cdot f i / N}}{\bar{Y}}$

di mana: Iw $=$ Indeks Williamson; $Y i=$ PDRB per kapita kabupaten/kota ke i; $\bar{\Upsilon}=$ rerata PDRB per kapita kabupaten/kota di DAS; $\mathrm{fi}=$ jumlah penduduk kabupaten/kota ke i; $\mathrm{N}=$ jumlah penduduk kabupaten/kota di DAS.

Indeks kesenjangan Williamson akan menghasilkan indeks antara 0 sampai dengan 1 . Nilai indeks yang mendekati 1 menunjukkan kondisi ketidakmerataan yang nyata, sedangkan nilai indeks yang mendekati nol menunjukkan kondisi yang relatif merata. Semakin besar nilai indeks yang dihasilkan, maka semakin besar tingkat disparitas pendapatan antar kabupaten dalam suatu DAS. Kriteria yang dipergunakan untuk menentukan taraf ketimpangan berdasarkan kriteria Oshima yang diacu oleh Puspandika (2007) dan Putra (2011), yaitu:

$$
\begin{array}{ll}
\mathrm{Iw}<0,35 & : \text { Ketimpangan taraf rendah } \\
0,35<\mathrm{Iw}<0,50 & : \text { Ketimpangan taraf menengah } \\
\mathrm{Iw}>0,50 & : \text { Ketimpangan taraf tinggi }
\end{array}
$$

Perkembangan ketimpangan ekonomi antar kabupaten dapat diamati dari grafik perkembangan tahunan indeks Wiliamson yang diperoleh.

\section{Sektor-Sektor Ekonomi Unggulan}

Sektor-sektor ekonomi unggulan diidentifikasi menggunakan analisis Location Quotient (LQ). Location Quotient merupakan suatu metode analisis yang umum digunakan sebagai penentu analisis ekonomi basis. Rustiadi et al., (2011) menyatakan bahwa LQ dapat mengetahui potensi aktivitas ekonomi yang merupakan sektor basis dan bukan sektor basis yang merupakan perbandingan relatif antara kemampuan sektor yang sama pada daerah yang lebih luas dalam suatu wilayah. Dalam penelitian ini, LQ dipakai untuk menentukan sektor unggulan dengan pendekatan nilai tambah (PDRB) kabupaten dalam DAS dan PDRB dalam suatu DAS, dirumuskan sebagai berikut:

$$
L Q=\frac{p i / p t}{P i / P t}
$$

di mana: $\mathrm{pi}=$ nilai PDRB sektor $\mathrm{i}$ di kabupaten $\mathrm{j} ; \mathrm{pt}$ $=$ total PDRB di kabupaten $\mathrm{j} ; \mathrm{Pi}=$ nilai PDRB sektor i pada tingkat DAS; Pt = total PDRB pada tingkat DAS.
Nilai LQ diinterpretasikan dengan menggunakan kriteria (Muljaningsih, 2008; Titisari, 2009; Ronhood, 1988 dalam Sari 2010; Jamaliah dan Kurniawan, 2010) sebagai berikut:

Jika nilai LQ $>1$ menunjukkan sektor bersangkutan merupakan sektor basis yang menjadi kekuatan kabupaten untuk mengekspor produknya keluar kabupaten, relatif terkonsentrasi di kabupaten yang bersangkutan dibandingkan pada tingkat DAS, dan memiliki keunggulan komparatif.

Jika nilai $\mathrm{LQ}=1$ menunjukkan kecenderungan sektor bersangkutan bersifat tertutup karena tidak melakukan transaksi ke dan dari luar kabupaten. Namun kondisi ini sulit ditemukan dalam perekonomian kabupaten atau berarti konsentrasi sektor bersangkutan sama dengan rata-rata di tingkat nasional. Hal ini berarti pula bahwa sektor bersangkutan tidak memiliki keunggulan komparatif, produksi sektor yang dihasilkan hanya cukup untuk memenuhi kebutuhan sendiri dalam kabupaten bersangkutan.

Jika nilai LQ $<1$ menunjukkan sektor bersangkutan menjadi pengimpor atau pangsa sektor bersangkutan lebih kecil dibandingkan dengan pangsa sektor bersangkutan di tingkat DAS. Ini menunjukkan bahwa sektor bersangkutan merupakan sektor non basis, artinya produksi sektor bersangkutan di suatu kabupaten tidak memiliki keunggulan komparatif, produksi sektor bersangkutan di kabupaten tidak dapat memenuhi kebutuhan sendiri dan harus mendapat pasokan dari luar kabupaten.

Untuk menentukan sektor unggulan di suatu kabupaten, maka nilai LQ dari suatu sektor yang bersangkutan harus lebih besar dari 1. Nilai LQ yang semakin lebih tinggi dari 1 menunjukkan adanya keunggulan komparatif yang semakin tinggi.

\section{Kontribusi sektoral}

Kontribusi sektoral menunjukkan peran atau sumbangan suatu sektor tertentu terhadap perkembangan ekonomi kabupaten yang merupakan perbandingan antara sumbangan ekonomi sektoral terhadap besarnya PDRB suatu kabupaten yang dinyatakan dalam persentase. Semakin besar nilai persentase suatu sektor terhadap PDRB menunjukkan semakin besarnya peran sektor bersangkutan dalam suatu perekonomian. 


\section{HASIL DAN PEMBAHASAN}

\section{A. Ekonomi Penduduk Kabupaten dalam Sub DAS Bengawan Solo Hulu}

Sub DAS Bengawan Solo Hulu merupakan salah satu bagian dari DAS Bengawan Solo. Sebagian besar wilayahnya berada di Provinsi Jawa Tengah. Ekonomi dan penduduk Sub DAS Bengawan Solo Hulu disajikan pada Tabel 2, sedangkan pertumbuhan dan PDRB per kapita disajikan pada Tabel 3.

Dari Tabel 2 diketahui bahwa sekitar 70\% PDRB Sub DAS Bengawan Solo Hulu berasal dari 3 kabupaten yaitu Karanganyar (25,50\%), Klaten $(24,41 \%)$, dan Boyolali (20,90\%), sedangkan dari Tabel 3 diketahui pertumbuhan ekonomi tertinggi terjadi di Karanganyar (5,47\%). Dari Tabel 3 juga diketahui bahwa 44\% penduduk tinggal di Kabupaten Klaten $(24,08 \%)$ dan Wonogiri
(20,81\%). Pada periode 2000-2011,pendapatan per kapita penduduk Karanganyar, Boyolali, dan Klaten lebih tinggi dibanding penduduk lain di Sub DAS Bengawan Solo Hulu. Pada Tabel 3 terlihat terdapat peningkatan pertumbuhan ekonomi di Kabupaten Wonogiri (3,21\% periode 2000-2005 menjadi 4,37\% periode 2006-2011), Boyolali (4,25\% periode $2000-2005$ menjadi $4,39 \%$ periode 2006-2011), dan Sragen (4,02\% periode 2000-2005 menjadi $5,87 \%$ periode 2006-2011). Perlu ditambahkan bahwa pada periode 2000-2005 Kabupaten Klaten tergolong sebagai kabupaten dengan pertumbuhan ekonomi (4,54\%) dan pendapatan per kapita (Rp3,31 juta) di atas rerata Sub DAS (rerata pertumbuhan ekonomi Sub DAS: 4,31\%, sedangkan pendapatan per kapita: Rp3,24 juta), namun pada periode 2006-2011 menjadi daerah terbelakang dengan pertumbuhan ekonomi $(2,90 \%)$ dan pendapatan per kapita (Rp4,09 juta) di bawah rerata Sub DAS (rerata pertumbuhan

Tabel 2. Ekonomi dan penduduk lima kabupaten di Sub DAS Bengawan Solo Hulu, rerata 2000 - 2011

Table 2. Economic andpopulation conditions of five regencies in Upper Bengawan Solo sub watershed, on average of 2000 2011

\begin{tabular}{lrrrr}
\hline \multirow{2}{*}{$\begin{array}{c}\text { Kabupaten } \\
\text { (Regency) }\end{array}$} & \multicolumn{2}{c}{ PDRB konstan (Constant GRDP) } & \multicolumn{2}{c}{ Penduduk (Population) } \\
\cline { 2 - 5 } & $\mathrm{Rp}($ miliar/billion) & Porsi (Share) $(\%)$ & $\begin{array}{c}\text { Jumlah (Total) } \\
\text { (jiwa/person) }\end{array}$ & $\begin{array}{c}\text { Porsi } \\
(\text { Share })(\%)\end{array}$ \\
\hline Wonogiri & 2535,50 & 14,82 & 976415 & 20,81 \\
Karanganyar & 4362,18 & 25,50 & 803217 & 17,12 \\
Boyolali & 3575,99 & 20,90 & 925461 & 19,72 \\
Sragen & 2460,37 & 14,38 & 857706 & 18,28 \\
Klaten & 4175,75 & 24,41 & 1130114 & 24,08 \\
\hline Jumlah DAS Solo Hulu & 17109,78 & 100,00 & 4692913 & 100,00 \\
\hline
\end{tabular}

Keterangan (Remark): PDRB dihitung berdasarkan harga konstan dengan tahun dasar 2000 (GRDPcalculated based on constant prices with base year 2000).

Tabel3. Pertumbuhan ekonomi dan PDRB per kapita lima kabupaten di Sub DAS Bengawan Solo Hulu, rerata 2000 - 2011

Table 3. Economic growth and GRDP per capita of five regencies in Upper Bengawan Solo sub watershed, on average of $2000-2011$

\begin{tabular}{lrrrrrr}
\hline \multirow{2}{*}{$\begin{array}{c}\text { Kabupaten } \\
\text { (Regency) }\end{array}$} & \multicolumn{2}{c}{$\begin{array}{c}\text { Pertumbuhan ekonomi (\%) } \\
\text { (Economic growth in \%) }\end{array}$} & \multicolumn{3}{c}{$\begin{array}{c}\text { PDRB per kapita (juta Rp) } \\
\text { (GDP per capita in million Rp) }\end{array}$} \\
\cline { 2 - 7 } & $2000-2005$ & $2006-2011$ & $2000-2011$ & $2000-2005$ & 2006-2011 & $2000-2011$ \\
\hline Wonogiri & 3,21 & 4,37 & 3,84 & 2,32 & 3,04 & 2,73 \\
Karanganyar & 5,52 & 5,43 & 5,47 & 4,70 & 6,26 & 5,60 \\
Boyolali & 4,25 & 4,39 & 4,33 & 3,44 & 4,32 & 3,95 \\
Sragen & 4,02 & 5,87 & 5,03 & 2,44 & 3,30 & 2,93 \\
Klaten & 4,54 & 2,90 & 3,65 & 3,31 & 4,09 & 3,77 \\
\hline DAS Solo Hulu & 4,31 & 4,59 & 4,46 & 3,24 & 4,20 & 3,79 \\
\hline
\end{tabular}


ekonomi Sub DAS: 4,59\%, sedangkan pendapatan per kapita: Rp 4,20 juta). Sedangkan Kabupaten Sragen yang tertinggal pada periode 2000-2005 menjadi daerah maju tapi kemudian tertekan pada periode 2006-2011 dengan pertumbuhan ekonomi di atas rerata meskipun pendapatannya masih di bawah rerata Sub DAS. Perubahan ini menunjukkan dinamisnya perkembangan ekonomi di dalam Sub DAS.

\section{B. Pola dan Struktur Pertumbuhan Ekonomi}

Pola dan struktur pertumbuhan ekonomi daerah kabupaten di Sub DAS Bengawan Solo Hulu dianalisis menggunakan tipologi Klassen yang mendasarkan pada dua indikator, yaitu: pertumbuhan ekonomi dan PDRB per kapita. Hasil analisis berdasarkan tipologi Klassen menunjukkan bahwa daerah kabupaten/kota di Sub DAS Bengawan Solo Hulu dapat dikelompokkan menjadi 4 tipe (Gambar 1). Tipologi 1 merupakan daerah cepat maju dan cepat tumbuh yaitu daerah yang memiliki pertumbuhan ekonomi dan pendapatan per kapita di atas rerata. Tipologi 2 merupakan daerah maju tetapi tertekan yaitu daerah yang memiliki pendapatan lebih tinggi tetapi tingkat pertumbuhan ekonominya lebih rendah dari rerata. Tipologi 3 merupakan daerah berkembang cepat yaitu daerah yang memiliki pertumbuhan ekonomi tinggi tetapi tingkat pendapatan per kapita lebih rendah dari rerata. Tipologi 4 merupakan daerah tertinggal yang memiliki pertumbuhan ekonomi dan pendapatan per kapita lebih rendah dari rerata.

Dari Gambar 1 diketahui bahwa daerah kabupaten/kota di Sub DAS Bengawan Solo Hulu yang termasuk daerah maju dan berkembang pesat adalah Karanganyar. Kemajuan dan perkembangan daerah ini ditunjukkan dengan pertumbuhan ekonomi dan pendapatan per kapita yang lebih besar dibanding rerata daerah lain yang berada di Sub DAS Bengawan Solo Hulu. Sedangkan Sragen termasuk kategori daerah berkembang pesat dengan pertumbuhan di atas rerata pertumbuhan ekonomi Sub DAS Bengawan Solo Hulu, meskipun pendapatan perkapitanya lebih rendah dari rerata pendapatan perkapita Sub DAS Bengawan Solo Hulu. Kabupaten Sragen mempunyai potensi besar untuk berkembang tetapi belum dikelola dengan baik sehingga meskipun perkembangan ekonominya cepat tetapi pendapatan perkapita masih lebih rendah dibanding rerata pendapatan per kapita daerah lain. Daerah Boyolali termasuk daerah maju tapi tertekan perkembangan ekonominya karena terhambatnya kegiatan utama kabupaten ini dalam perekonomian daerah. Kabupaten Wonogiri yang merupakan daerah paling hulu di Sub DAS Bengawan Solo Hulu merupakan daerah yang tertinggal dilihat dari pertumbuhan ekonomi dan PDRB per kapitanya.

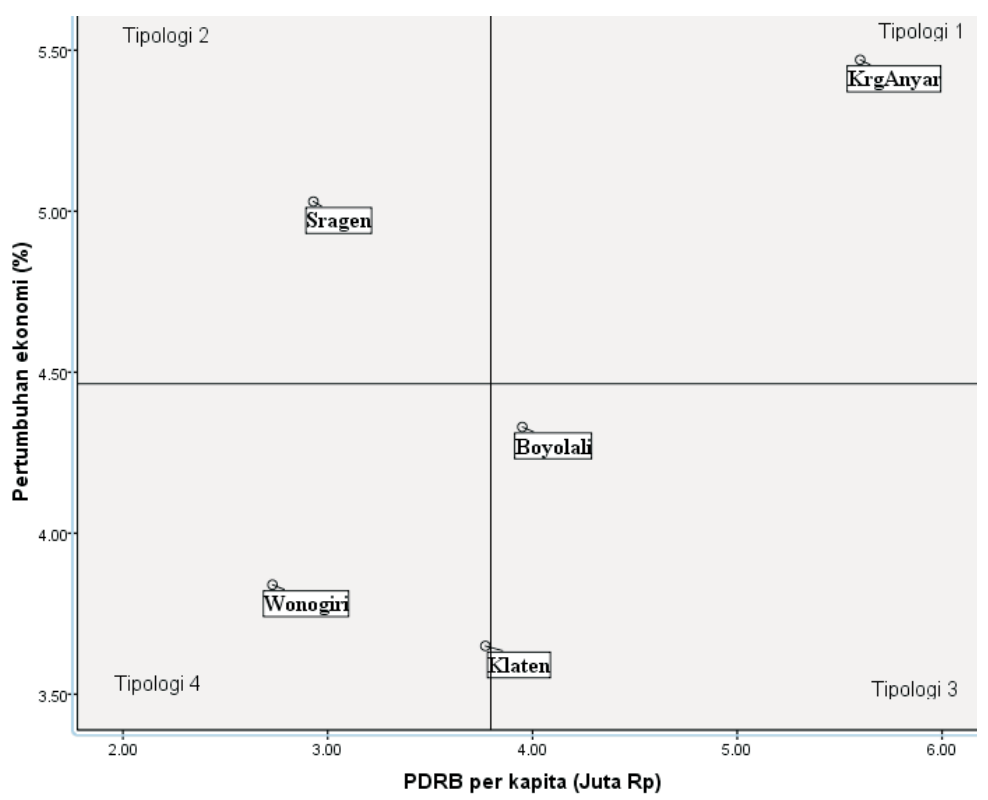

Gambar 1. Pola dan struktur pertumbuhan ekonomi Sub DAS Bengawan Solo Hulu, 2000-2011 Figure 1. Structure and pattern of economic growth in Upper Bengawan Solo sub watershed, 2000-2011 


\section{Disparitas Pendapatan Antar Kabupaten}

Disparitas pendapatan antar kabupaten dianalisis menggunakan indeks Williamson. Hasil analisis perkembangan disparitas pendapatan antar kabupaten di Sub DAS Bengawan Solo Hulu berdasarkan indeks Williamson disajikan pada Gambar 2.

Dari Gambar 2 diketahui bahwa rerata disparitas pendapatan antar kabupaten di Sub DAS Bengawan Solo Hulu periode 2000-2011 adalah 0,25 (ketimpangan taraf rendah) dengan kecenderungan yang meningkat. Hal ini dikarenakan sebagian besar kabupaten di Bengawan Solo Hulu ekonominya masih berbasis agraris (primer) dan baru mulai mentransformasi ekonominya ke sektor industri (sekunder). Hasil penelitian ini berbeda dengan beberapa hasil penelitian di Provinsi Jawa Tengah yang menunjukkan nilai ketimpangan tinggi (Sudarmono, 2006: 0,68 dalam periode 1983-1993, Suhartono, 2011): 0,97 dalam periode tahun 2002 2006, Damarjati, 2010: 0,6626 dalam periode 20032007) meskipun selaras dengan hasil penelitian Isnowati (2007), yang menyimpulkan bahwa ketimpangan di Jawa Tengah cenderung semakin besar. Perbedaan hasil penelitian yang diperoleh dapat dipahami karena perbedaan jumlah kabupaten yang dianalisis, perbedaan tahun, dan cakupan wilayah.

Koefisien ketimpangan yang tinggi di Jawa Tengah disebabkan oleh pola pembangunan ekonomi yang lebih berorientasi sektoral, di mana sektor industri dan pengolahan, listrik, gas dan air bersih, bangunan dan konstruksi, perdagangan, komunikasi dan angkutan, keuangan serta jasa-jasa diutamakan untuk memacu pertumbuhan ekonomi yang tinggi. Sektor-sektor ekonomi tersebut biasanya dikembangkan pada lokasi tertentu yang menguntungkan dan sesuai bagi pengembangan suatu sektor tertentu. Lokasi yang dipilih pada umumnya di daerah yang telah mempunyai berbagai prasarana dan fasilitas penunjang untuk pengembangan sektor-sektor tertentu. Temuan Pambudi dan Miyasto (2013) menunjukkan bahwa investasi dan tenaga kerja menentukan pertumbuhan ekonomi Jawa Tengah. Daerah yang ekonominya secara historis telah berkembang menjadi semakin berkembang, sementara daerah yang ekonominya belum berkembang sulit mengejar perkembangan ekonomi daerah yang telah berkembang.

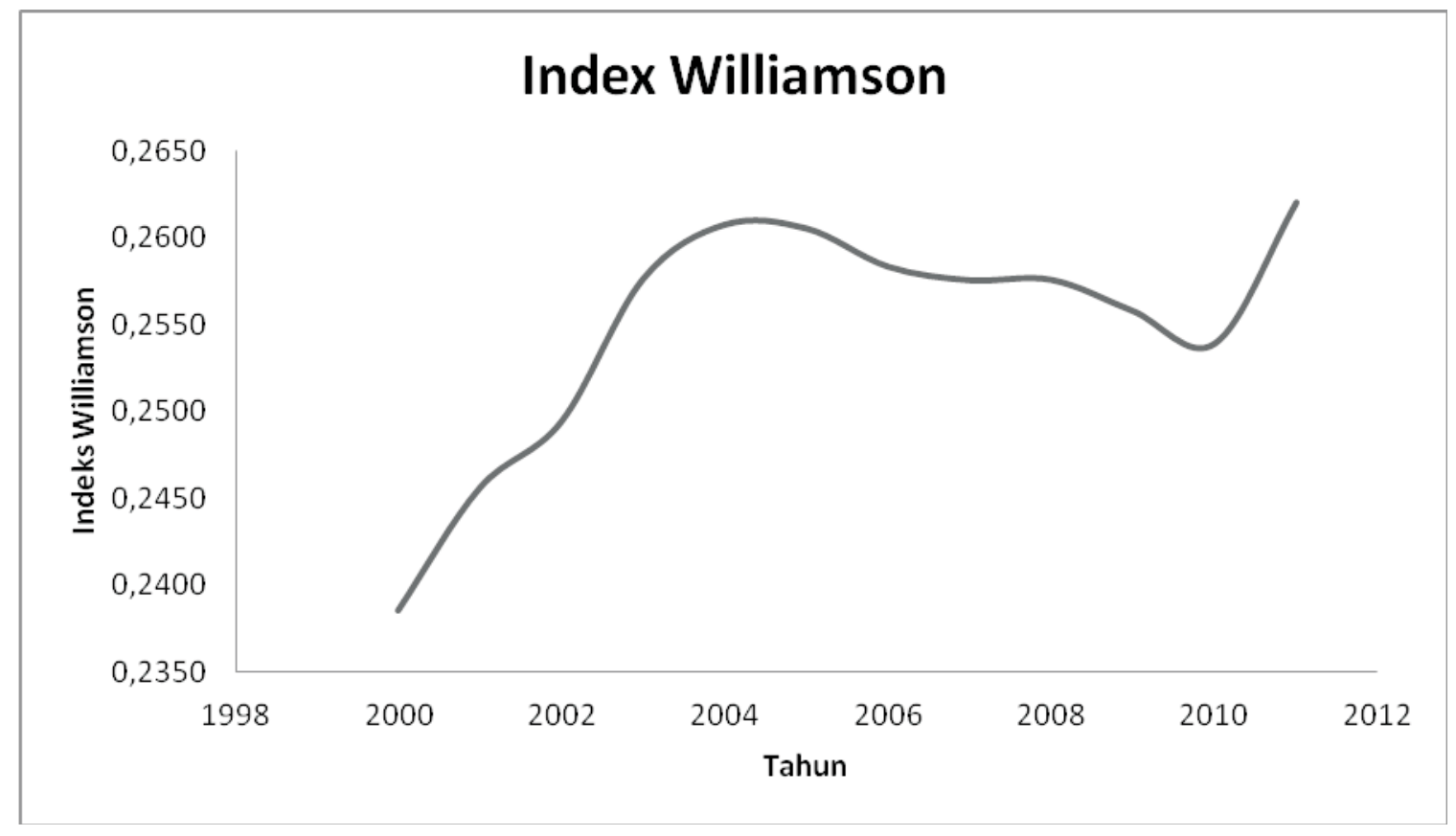

Gambar2. Perkembangan disparitas pendapatan antar kabupaten di Sub DAS Bengawan Solo Hulu berdasarkan indeks Williamson, 2000-2011

Figure 2. Development of inter-regency income disparity in upper Bengawan Solo sub watershed based on Williamson index, 2000-2011 


\section{Identifikasi dan Kontribusi Sektor Ekonomi Unggulan}

Untuk mempercepat pembangunan ekonomi diperlukan fokus pengembangan sektor ekonomi yang mampu meningkatkan pertumbuhan ekonomi dan menarik pertumbuhan sektor-sektor ekonomi lain (Adisasmita, 2013). Sektor terpilih harus memiliki pertumbuhan yang positif, yang ditunjukkan oleh nilai LQ lebih besar dari satu, sedangkan sektor-sektor yang mengalami pertumbuhan negatif, ditunjukkan oleh nilai LQ lebih kecil dari satu. Hasil perhitungan LQ tiap kabupaten di Sub DAS Bengawan Solo Hulu disajikan pada Tabel 4.

Pada Tabel 4 diketahui bahwa sektor jasa dapat dikembangkan di 4 kabupaten yakni Wonogiri, Boyolali, Sragen, dan Klaten, sedangkan sektor pertanian, peternakan, kehutanan, dan perikanan di tiga kabupaten yakni Wonogiri, Boyolali, dan Sragen. Sektor listrik gas dan air bersih dapat dikembangkan di tiga kabupaten yakni Karanganyar, Boyolali, dan Sragen, sedangkan sektor keuangan, real estate dan jasa perusahaan di tiga kabupaten yakni Wonogiri, Boyolali, dan Sragen. Sektor pertambangan dan penggalian dapat dikembangkan di dua kabupaten yakni
Boyolali dan Klaten, sedangkan sektor konstruksi dapat dikembangnkan di dua kabupaten yakni Sragen dan Klaten. Sektor perdagangan, hotel dan restoran dapat dikembangkan di dua kabupaten yakni Boyolali dan Klaten, sedangkan sektor industri pengolahan hanya di Karanganyar, sektor pengangkutan dan komunikasi hanya di Wonogiri.

Hasil penelitian Wicaksono (2010) menjelaskan bahwa sektor industri pengolahan dan sektor pertanian termasuk sektor yang berpotensi untuk mendorong pertumbuhan ekonomi tiap kabupaten/kota di Provinsi Jawa Tengah. Kajian Soleh (2012) juga menunjukkan bahwa Jawa Tengah adalah unggul dalam industri manufaktur atau pengolahan terutama industri minyak dan lemak, sektor industri kayu dan bahan bangunan dari kayu, dan sektor listrik dan gas. Namun di Sub DAS Bengawan Solo Hulu hanya terdapat satu daerah yang potensial untuk pengembangan industri pengolahan yaitu Kabupaten Karanganyar, sedangkan untuk pengembangan pertanian, peternakan, kehutanan dan perikanan di tiga kabupaten, yaitu: Wonogiri, Boyolali, dan Sragen. Ini menunjukkan bahwa sektor agraris masih dominan pada perekonomian di Sub DAS Bengawan Solo Hulu.

Tabel 4. Sektor-sektor ekonomi unggulan kabupaten di Sub DAS Bengawan Solo Hulu berdasarkan Location Quotient

Table 4. Leading sectors of regencies in upper Bengawan Solo sub watershed based on Location Quotient

\begin{tabular}{|c|c|c|c|c|c|c|}
\hline No & Sektor (Sector) & Wonogiri & Karanganyar & Boyolali & Sragen & Klaten \\
\hline 1 & $\begin{array}{l}\text { Pertanian, peternakan, kehutanan, } \\
\text { perikanan (Agriculture, livestock, } \\
\text { forestry, fisheries) }\end{array}$ & 1,72 & 0,70 & 1,12 & 1,14 & 0,69 \\
\hline 2 & $\begin{array}{l}\text { Pertambangan dan penggalian } \\
\text { (Mining and quarrying) }\end{array}$ & 0,92 & 0,88 & 1,12 & 0,32 & 1,51 \\
\hline 3 & $\begin{array}{l}\text { Industri pengolahan(Processing } \\
\text { industry) }\end{array}$ & 0,18 & 2,01 & 0,64 & 0,87 & 0,78 \\
\hline 4 & $\begin{array}{l}\text { Listrik, Gas dan air bersih } \\
\text { (Electricity, gas, and water supply) }\end{array}$ & 0,54 & 1,26 & 1,25 & 1,13 & 0,70 \\
\hline 5 & Konstruksi (Construction) & 0,99 & 0,54 & 0,66 & 1,01 & 1,80 \\
\hline 6 & $\begin{array}{l}\text { Perdagangan, hotel dan restoran } \\
\text { (Trade, hotels, and restaurants) }\end{array}$ & 0,68 & 0,53 & 1,28 & 0,97 & 1,49 \\
\hline 7 & $\begin{array}{l}\text { Pengangkutan dan komunikasi } \\
\text { (Transportation and communication) }\end{array}$ & 2,40 & 0,72 & 0,72 & 0,87 & 0,77 \\
\hline 8 & $\begin{array}{l}\text { Keuangan, real estat dan jasa } \\
\text { perusahaan (Finance, real estate and } \\
\text { business services) }\end{array}$ & 1,07 & 0,52 & 1,60 & 1,01 & 0,96 \\
\hline 9 & Jasa-jasa (Services) & 1,09 & 0,72 & 1,00 & 1,05 & 1,23 \\
\hline
\end{tabular}


Dari Tabel 4 juga diketahui bahwa Kabupaten Wonogiri memiliki 4 sektor unggulan namun yang paling potensial dapat dikembangkan adalah sektor pengangkutan dan komunikasi $(\mathrm{LQ}=2,4)$. Hal ini didukung dengan banyaknya pengusaha transportasi di Wonogiri, terutama transportasi hasil pertanian dan angkutan penumpang antar kota (bus). Kabupaten Karanganyar dapat mengembangkan sektor industri pengolahan $(2,01)$ dan sektor listrik, gas dan air bersih $(1,26)$. Sektor industri pengolahan/manufaktur di kabupaten ini adalah potensial untuk dikembangkan dan infrastruktur yang tersedia mendukung dibandingkan dengan kabupaten lain. Boyolali memiliki 6 sektor unggulan namun yang paling potensial dapat dikembangkan adalah sektor keuangan, real estate dan jasa perusahaan $(1,60)$. Kabupaten Sragen memiliki 5 sektor unggulan namun yang paling potensial dikembangkan adalah sektor pertanian, peternakan, kehutanan dan perikanan $(1,14)$. Kabupaten Klaten memiliki 4 sektor unggulan namun yang paling potensial dikembangkan adalah sektor konstruksi $(1,80)$.

Sektor unggulan setiap kabupaten bervariasi baik jumlah maupun jenisnya tergantung pada sumberdaya dan keunggulan komparatif sektor di tiap daerah. Ketersediaan sumberdaya (alam, manusia, modal, dan lainnya), infrastruktur, kebijakan pendukung dan lainnya akan mempengaruhi perkembangan sektor unggulan tersebut. Sektor-sektor unggulan pada umumnya memberikan kontribusi yang relatif signifikan terhadap perkembangan ekonomi daerah (PDRB). Semakin besar kontribusinya terhadap PDRB menunjukkan peran dan strategis sektor tersebut dalam pembangunan daerah. Kontribusi sektoral terhadap PDRB setiap kabupaten di Sub DAS Solo hulu disajikan pada Tabel 5.

Dari Tabel 5 diketahui bahwa sektor pengangkutan dan komunikasi mendominasi PDRB Wonogiri $(35,21 \%)$, sedangkan perekonomian Kabupaten Karanganyar didominasi oleh sektor industri pengolahan $(52,76 \%)$. Sumbangan sektor ekonomi terbesar dalam PDRB Kabupaten Boyolali berasal dari sektor keuangan, real estate dan jasa perusahaan (32,96\%). Perekonomian Kabupaten Sragen cukup berimbang antar sektor dengan sumbangan terbesar dari sektor pertanian, peternakan, kehutanan dan perikanan (16,89\%). Pembangunan ekonomi di Klaten didukung oleh sektor konstruksi yang menyumbang PDRB sebesar $42 \%$.

Tabel 5. Rerata kontribusi sektoral terhadap PDRB kabupaten di Sub DAS Bengawan Solo Hulu (dalam \%) Table 5. Average sectoral contribution to GRDP of regencies in upper Bengawan Solo sub watershed regency (in\%)

\begin{tabular}{|c|c|c|c|c|c|c|}
\hline No & Sektor (sector) & Wonogiri & Karanganyar & Boyolali & Sragen & Klaten \\
\hline 1 & $\begin{array}{l}\text { Pertanian, peternakan, kehutanan, } \\
\text { perikanan (Agriculture, livestock, } \\
\text { forestry, fisheries) }\end{array}$ & 25,18 & 18,53 & 23,17 & 16,89 & 16,22 \\
\hline 2 & $\begin{array}{l}\text { Pertambangan dan penggalian } \\
\text { (Mining and quarrying) }\end{array}$ & 13,55 & 23,07 & 23,07 & 4,76 & 35,55 \\
\hline 3 & $\begin{array}{l}\text { Industri pengolahan (Processing } \\
\text { industry) }\end{array}$ & 2,70 & 52,76 & 13,17 & 12,87 & 18,50 \\
\hline 4 & $\begin{array}{l}\text { Listrik, Gas dan air bersih } \\
\text { (Electricit), gas, and water supply) }\end{array}$ & 7,99 & 33,11 & 25,73 & 16,66 & 16,51 \\
\hline 5 & Konstruksi (Construction) & 14,56 & 14,19 & 13,67 & 14,98 & 42,60 \\
\hline 6 & $\begin{array}{l}\text { Perdagangan, hotel dan restoran } \\
\text { (Trade, hotels, and restaurants) }\end{array}$ & 10,03 & 13,95 & 26,53 & 14,37 & 35,12 \\
\hline 7 & $\begin{array}{l}\text { Pengangkutan dan komunikasi } \\
\text { (Transportation and communication) }\end{array}$ & 35,21 & 18,93 & 14,95 & 12,79 & 18,12 \\
\hline 8 & $\begin{array}{l}\text { Keuangan, real estate dan jasa } \\
\text { perusahaan (Finance, real estate and } \\
\text { business services) }\end{array}$ & 15,68 & 13,72 & 32,96 & 14,95 & 22,68 \\
\hline \multirow[t]{2}{*}{9} & Jasa-jasa (Services) & 15,98 & 18,89 & 20,74 & 15,47 & 28,93 \\
\hline & DAS (W atershed) & 14,67 & 26,29 & 20,66 & 14,78 & 23,61 \\
\hline
\end{tabular}


Besarnya sumbangan sektoral menunjukkan peran strategis suatu sektor dalam suatu perekonomian.

\section{KESIMPULAN DAN SARAN}

\section{A. Kesimpulan}

1. Berdasarkan tipologi Klassen, pola dan struktur pertumbuhan ekonomi kabupaten di sub DAS Bengawan Solo Hulu bervariasi. Hasil kajian menunjukkan Kabupaten Karanganyar merupakan daerah yang perekonomiannya maju dan berkembang pesat, sedangkan Kabupaten Wonogiri tergolong daerah yang perekonomiannya tertinggal.

2. Perkembangan ekonomi kabupaten di Sub DAS Bengawan Solo Hulu dapat dipacu dengan pengembangan sektor unggulan. Sektor unggulan setiap kabupaten berbeda tergantung kondisi sumberdaya dan keunggulan komparatif yang dimiliki.

3. Sektor ekonomi unggulan Wonogiri adalah sektor pengangkutan dan komunikasi, sedangkan sektor unggulan Karanganyar adalah sektor industri pengolahan. Sektor ekonomi unggulan Boyolali adalah sektor keuangan, real estat dan jasa perusahaan, sedangkan Sragen adalah pertanian, peternakan, kehutanan, perikanan dan Kabupaten Klaten adalah sektor konstruksi.

4. Disparitas pendapatan antar kabupaten di Sub DAS Bengawan Solo Hulu relatif rendah (rataan Indeks Williamson periode 2000-2011 sebesar 0,25) namun cenderung meningkat. Rendahnya disparitas ini diduga karena struktur ekonomi kabupaten di Sub DAS Bengawan Solo Hulu memiliki kesamaan yakni lebih didominasi oleh sektor-sektor ekonomi yang berbasis agraris.

\section{B. Saran}

Pertumbuhan ekonomi dapat ditingkatkan dengan pengembangan sektor unggulan tiap kabupaten yaitu Wonogiri (pengangkutan dan komunikasi), Karanganyar (industri pengolahan), Boyolali (keuangan, real estat, dan jasa perusahaan), Sragen (pertanian, peternakan, kehutanan dan perikanan) dan Klaten (konstruksi). Disparitas ekonomi antar daerah yang rendah dengan kecenderungan meningkat karena sebagian besar daerah di Sub DAS Bengawan Solo Hulu masih menggantungkan sumber pendapatannya dari sektor yang berbasis agraris (sektor primer) dan baru mulai mengalami transformasi ekonomi ke sektor industri peng-olahan (sektor sekunder). Transformasi ekonomi dari sektor primer (agraris) ke sekunder (industri) harus dicermati agar tidak menimbulkan ke-timpangan pendapatan antar daerah. Untuk itu pe-ngembangan sektor unggulan perlu dilakukan secara inklusif, yaitu menyebar luas, merata, melibatkan dan dirasakan seluruh elemen masyarakat sehingga mengurangi disparitas ekonomi.

\section{DAFTAR PUSTAKA}

Adisasmita, R. (2013). Teori-teori pembangunan ekonomi: Pertumbuban ekonomi dan pertumbuban wilayah. Yogyakarta: Graha Ilmu.

Arifin, Z. (2009). Kesenjangan dan konvergensi ekonomi antar kabupaten pada empat koridor di Propinsi Jawa Timur. Humanity, 6, 154-164.

Arsyad, L. (1997). Ekonomi pembangunan. Yogyakarta: Bagian penerbitan STIE YKPN.

Arsyad, L. (1999). Pengantar perencanaan dan pembangunan ekonomi daerah. BPFE UGM. Yogyakarta.

Balai Besar Wilayah Sungai Bengawan Solo [BBWS Bengawan Solo]. (2012). Profil pengelolaan sumberdaya air wilayah sungai Bengawan Solo. Surakarta: Direktorat Jenderal Sumberdaya Air. Kementerian Pekerjaan Umum.

Caska \& Riadi, R.M. (2008). Pertumbuhan dan ketimpangan pembangunan ekonomi antar daerah di Provinsi Riau. Jurnal Industri dan Perkotaan, 12, 1629-1642.

Chaniago, J. (2009). Mengenal Tipologi Klassen. http://junaidichaniago.blogspot.com/2009 105/mengenal-tipologi-klassen-seri $1 . \mathrm{html}$. diakses: 5 Oktober 2013.

Damarjati, A.G. (2010). Analisis faktor-faktor yang mempengaruhi kesenjangan pendapatan di Propinsi Jawa Tengah. Skripsi tidak 
dipublikasikan. Semarang: Fakultas Ekonomi Universitas Diponegoro.

Emilia \& Imelia. (2006). Modul ekonomi regional. (Modul). Jambi: Fakultas Ekonomi Universitas Jambi.

Ernita, D., Amar, A., \& Syofyan, E. (2013). Analisis pertumbuhan ekonomi, investasi, dan konsumsi di Indonesia. Jurnal Kajian Ekonomi, 1, 176-193.

Khairullah \& Cahyadin, M. (2006). Evaluasi pemekaran wilayah di Indonesia: studi kasus Kabupaten Lahat. Jurnal Ekonomi Pembangunan, 11, 261-277.

Hidayati, R.A. (2008). Analisis ketimpangan ekonomi antar kecamatan di Kabupaten Gresik. JurnalLogos, 6, 83-97.

Isnowati, S. (2007). Pengujian hipotesis Kuznets di wilayah pembangunan I Jawa Tengah. Jurnal Bisnis dan Ekonomi, 14, 1-14.

Isnowati, S. (2012). Penerapan model Kweka dan Morissey dalam menerangkan pertumbuhan ekonomi di Jawa Tengah. Jurnal Bisnis dan Ekonomi, 19, 25-36.

Jamaliah \& Kurniawan, A. (2010). Analisis struktur ekonomi serta basis ekonomi di Propinsi Kalimantan Barat. Jurnal Ekonomi, Bisnis dan Kewirausahaan, 1, 67-81.

Jonaidi, A. (2012). Analisis pertumbuhan ekonomi dan kemiskinan di Indonesia. Jurnal Kajian Ekonomi, 1, 140-164.

Kuncoro, M. (2004). Otonomi dan pembangunan daerah: Reformasi, perencanaan, strategi dan peluang. Jakarta: Erlangga.

Muljaningsih, S. (2008). Keberadaan pasar memberikan multiplier efect terhadap pengembangan ekonomi wilayah: studi kasus di lingkup wilayah Pasar Gempol Kab. Pasuruan Prop. Jawa Timur. Jurnal Agribisnis Kerakyatan, 1, 16-47.

Nippon Koei. (2001). Laporan Comprehensive Development and Management Plan (CDMP) study for Bengawan Solo River basin. (Laporan). Jakarta: Nippon Koei.

Pambudi, E.W., \& Miyasto. (2013). Analisis pertumbuhan ekonomi dan faktor-faktor yang mempengaruhi kabupaten/kota di provinsi Jawa Tengah. Diponegoro Journal of Economics, 2,1-13.

PPE Jawa. (2014). DAS Bengawan Solo. Kementerian Lingkungan Hidup. http://ppejawa.com/ ekoregion/das-bengawan-solo/. Diakses: 25 Februari 2014.

Pujiati, A. (2009). Analisis kawasan andalan di Jawa Tengah. Aset, 11, 117-128.

Puspandika, B.A. (2007). Analisis ketimpangan pembangunan di era otonomi daerah: Hubungan antara pertumbuhan ekonomi dan kesejahteraan masyarakat. Skripsi tidak dipublikasikan. Bogor: Fakultas Ekonomi dan Manajemen Institut Pertanian Bogor.

Putra, L.D. (2011). Analisis pengaruh ketimpangan distribusi pendapatan terhadap jumlah penduduk miskin di Provinsi Jawa Tengah periode 2000-2007. Skripsi tidak dipublikasikan. Semarang: Fakultas Ekonomi Universitas Diponegoro.

Rachman, M.R. (2010). Analisis investasi terhadap tingkat kesejahteraan dan pertumbuhan ekonomi di Kabupaten Gresik, Sidoarjo dan Pasuruan. Skripsi tidak dipublikasikan. Jawa Timur: Fakultas Ekonomi Universitas Pembangunan Nasional Veteran. Restiatun. (2009). Identifikasi sektor unggulan dan ketimpangan antar kabupaten/kota di Propinsi daerah Istimewa Yogyakarta. Jurnal Ekonomi dan Studi Pembangunan, 10, 77-98.

Rustiadi, E., Saefulhakim., \& Panuju, D.R. (2011). Perencanaan dan Pengembangan Wilayah. Jakarta: Yayasan Pustaka Obor Indonesia.

Sari, R.M. (2010). Analisis komoditas unggulan pertanian di Pulau Buru, Provinsi Maluku. Jurnal Agroforestry, 5, 228-236.

Shin, I. (2012). Income inequality and economic growth. Economic Modelling, 29, 2049-2057.

Sjafrizal. (2012). Ekonomi wilayah dan perkotaan. Jakarta: Rajagrafindo Persada.

Soleh, A. (2012). Kontribusi dan daya saing ekspor sektor unggulan dalam perekonomian Jawa Tengah. Skripsi tidak dipublikasikan. Semarang: Fakultas Ekonomi Universitas Diponegoro. 
Sudarmono, M. (2006). Analisis transformasi struktural pertumbuhan ekonomi dan ketimpangan antar daerah di wilayah pembangunan I Jateng. Tesis tidak dipublikasikan. Semarang: Program Pasca Sarjana Universitas Diponegoro.

Sufirmansyah. (2012). Dampak kebijakan desentralisasi fiskal terhadap pertumbuhan ekonomi, ketimpangan antar daerah, dan kemiskinan. Jurnal Ekonomi dan Pembangunan, 3,136-148.

Suhartono. (2011). Struktur ekonomi, kesempatan kerja dan ketimpangan pendapatan di Provinsi Jawa Tengah. Jurnal Organisasi dan Manajemen, 7, 86-101.

Sukirno, S. (1994). Pengantar makroekonomi. (Edisi kedua). Jakarta: PT. Grafindo.

Sutarno \& Kuncoro, M. (2003). Pertumbuhan ekonomi dan ketimpangan antar kecamatan di Kabupaten Banyumas, 1993-2000. Jurnal Ekonomi Pembangunan, 8, 97-110.

Syam, A. (2003). Sistem pengelolaan lahan kering di daerah aliran sungai bagian hulu. Jurnal Litbang Pertanian, 22, 162-171.
Tambunan, T.T.H. (2003). Perekonomian Indonesia: Beberapa masalah penting. Jakarta: Ghalia Indonesia.

Titisari, K.H. (2009). Identifikasi potensi ekonomi daerah Boyolali, Karanganyar, dan Sragen. Jejak, 2, 167-182.

Van de Werfhorst, H.G., \& Salverda, W. (2012). Consequences of economic inequality: introduction to a special issue. Research in Social Stratification and Mobility, 30, 377-387.

Wardana, I.M. (2007). Analisis strategi pembangunan Provinsi Bali menuju balance growth. Buletin Studi Ekonomi, 12, 148-160.

Wicaksono, C.P. (2010). Analisis disparitas pendapatan antar kabupaten/kota dan pertumbuhan ekonomi di Propinsi Jawa Tengah tahun 2003-2007. Skripsi tidak dipublikasikan. Semarang: Fakultas Ekonomi Universitas Diponegoro.

Wikipedia. (2014). Bengawan Solo. http://id. wikipedia.org/wiki/Bengawan_Solo. diakses: 25 Februari 2014.

Wilonoyudho, S. (2009). Kesenjangan dalam pembangunan kewilayahan. Forum Geografi, 23,167-180. 